UDK 577.1 : 61

ISSN 1452-8258

J Med Biochem 40: 245-251, 2021

Original paper

Originalni naučni rad

\title{
INFLUENCE OF LIPID METABOLISM DISORDERS ON VENOUS THROMBOSIS RISK
}

\author{
UTICAJ POREMEĆAJA LIPIDNOG METABOLIZMA NA RIZIK OD VENSKE TROMBOZE \\ Igor Spasić1,3, Milan Ubavić2,3, Zorica Šumarac ${ }^{2,4}$, Maša Todorović1, Biljana Vučković ${ }^{1}$ \\ ${ }^{1}$ Department of Pathophysiology, Faculty of Medicine, University of Novi Sad, Novi Sad, Serbia \\ ${ }^{2}$ Faculty of Pharmacy Novi Sad, University Business Academy, Novi Sad, Serbia \\ ${ }^{3}$ Institute of Laboratory Diagnostics Medlab, Novi Sad, Serbia \\ ${ }^{4}$ Clinical Center of Serbia, Belgrade, Serbia
}

\section{Summary}

Background: To investigate the influence of lipid metabolism disorders on the risk of deep vein thrombosis.

Methods: A total of 200 subjects participated in the study, 100 of whom experienced DVT with or without PTE, and 100 healthy subjects representing the control group. We classified patients and controls in terms of serum concentrations of chylomicrons, LDL, IDL, VLDL, and HDL particles, as those with or without hyperlipoproteinemia and in terms of serum Lp (a) lipoprotein levels, as those with hyperLp (a) lipoproteinemia (serum $L p(a)$ values $>0.3$ $\mathrm{g} / \mathrm{L}$ ) and those without hyperLp (a) lipoproteinemia (serum $\mathrm{Lp}(\mathrm{a})$ values $<0.3 \mathrm{~g} / \mathrm{L}$ ). Based on the modified and supplemented Fredrickson classification, participants with verified existences of hyperlipoproteinemia were classified into subgroups based on the type of hyperlipoproteinemia. Unconditional logistic regression was used to calculate ORs with $95 \% \mathrm{Cls}$ as a measure of the relative risks for venous thrombosis in participants with hyperlipoproteinemia compared with those without hyperlipoproteinemia. The analysis was adjusted for all potential confounders (age, sex, obesity) related to the functionality of the lipid metabolism, and at the same time, may have an impact on the risk of venous thrombosis.

Results: The results of the comparison of the mean values of individual lipid status parameters between the patient group and the control group clearly indicate higher concentrations of total cholesterol $(5.93 \mathrm{mmol} / \mathrm{L}$ vs. 5.52

\section{Kratak sadržaj}

Uvod: Cilj je bio da se istraži uticaj poremećaja metabolizma lipida na rizik od razvoja tromboze dubokih vena. Metode: $U$ istraživanju je učestvovalo ukupno 200 ispitanika, od kojih je 100 doživelo DVT sa ili bez PTE i 100 zdravih ispitanika koji su predstavljali kontrolnu grupu. Pacijente i kontrolnu grupu klasifikovali smo prema serumskim koncentracijama hilomikrona, LDL, IDL, VLDL i HDL čestica, na one sa ili bez hiperlipoproteinemije i prema nivou Lp (a) lipoproteina u serumu, na one sa hiperLp (a) lipoproteinemijom (serumske vrednosti Lp (a) $>0,3 \mathrm{~g} / \mathrm{L}$ ) i one bez hiperLp (a) lipoproteinemije (vrednosti Lp (a) u serumu $<0,3 \mathrm{~g} / \mathrm{L}$ ). Na osnovu modifikovane i dopunjene Fredriksonove klasifikacije ispitanici sa dokazanim postojanjem hiperlipoproteinemije razvrstani su $\mathrm{u}$ podgrupe prema tipu hiperlipoproteinemije. Nekondicionalna logistička regresija je korištena za izračunavanje OR-a sa $95 \% \mathrm{Cl}$ kao mere relativnog rizika od venske tromboze kod ispitanika sa hiperlipoproteinemijom u poređenju sa onima bez hiperlipoproteinemije. Analiza je prilagođena za sve potencijalne »confoundere (uzrast, pol, gojaznost) koji se odnose na funkcionalnost metabolizma lipida, a istovremeno mogu imati uticaj na rizik od nastanka venske tromboze.

Rezultati: Rezultati poređenja srednjih vrednosti pojedinačnih parametara lipidnog statusa između grupe pacijenata i kontrolne grupe jasno ukazuju na veće koncentracije ukupnog holesterola $(5,93 \mathrm{mmol} / \mathrm{L}$ naspram 5,52

Address for correspondence:

Igor Spasić

Department of Laboratory Diagnostics Medlab, 21/15

Branimira Ćosića Street, 21000 Novi Sad, Vojvodina, Serbia

Phone: 060/3003811

e-mail: igsp92@gmail.com 
$\mathrm{mmol} / \mathrm{L})$, total triglycerides $(1.58 \mathrm{mmol} / \mathrm{L}$ vs. $1.50 \mathrm{mmol} / \mathrm{L})$, and LDL-cholesterol $(3.83 \mathrm{mmol} / \mathrm{L}$ vs. $3.44 \mathrm{mmol} / \mathrm{L}$ ) in the patient group relative to the control group, with a statistically significant difference observed only in the case of LDL-cholesterol concentrations. We have found that type Ila hyperlipoproteinemia is associated with a nearly double increased risk for deep vein thrombosis (OR 1.99; Cl 1.013.90), while type IIb, IV, or hyperLp (a) lipoproteinemia did not influence the risk (OR 1.22; 95\% Cl 0.79-1.84; OR 0.89 ; 95\% Cl 0.52-1.54 OR 1.85; 95\% Cl 0.84-4.04).

Conclusions: Hypercholesterolemia doubles the risk of deep vein thrombosis development.

Keywords: DVT, hemostasis, hyperlioproteinemia, lipidmetabolism, Lp (a) hyperlipoproteinemia

\section{Introduction}

Thrombosis represents a life-long intravascular or intracardiac formation of blood clots as a result of a disorder of the hemostatic mechanism, that is, its constituent factors such as platelets, coagulation factors, fibrinolysis factors, and inhibitors of coagulation and fibrinolysis.

The incidence of venous thrombosis in Europe is 160-180/100,000 (1). The clinical significance of venous thrombosis is reflected in high mortality rate (2), high recurrence rate (3), and complications that may occur after the first episode of venous thrombosis, described as a set of symptoms and signs collectively referred to as Postthrombotic Syndrome (PTS).

The underlying pathophysiological mechanism of venous thrombosis is explained by Virchow's Triassic, which implies the existence of slow blood flow and the termination of its laminar movement, a change in the vessel wall, and changes in blood composition $(4,5)$. The risk factors for DVT occurrence are roughly classified into those acquired and those that have been inherited. Some of the accepted acquired factors include age, immobilization, pregnancy and puerperium, malignancy, antiphospholipid antibodies, oral contraceptives, and hormone therapy, as well as life habits. As far as the inherited factors are concerned, these include factor $V$ Leiden mutation, factor II (prothrombin) G20210A mutation, deficiency of natural coagulation inhibitors (antithrombin, protein $\mathrm{C}$, protein S), and non-0 blood type (6-8). It is essential to emphasize the influence of the multiplication of risk factors, which basically shows that the combined effect of two or more risk factors multiplies their detrimental impact. For years, blood stasis was the most researched primary pathophysiological mechanism of vein thrombosis. More recent studies have made an effort to find a connection between the risk factors and pathophysiological mechanisms of arterial and venous thrombosis, based on the concept of endothelial dysfunction. Common risk factors for arterial and venous thrombosis include age, immobi- $\mathrm{mmol} / \mathrm{L})$, ukupnih triglicerida $(1,58 \mathrm{mmol} / \mathrm{L}$ naspram 1,50 $\mathrm{mmol} / \mathrm{L})$ i LDL-holesterola $(3,83 \mathrm{mmol} / \mathrm{L}$ naspram 3,44 $\mathrm{mmol} / \mathrm{L}$ ) u grupi pacijenata $\mathrm{u}$ odnosu na kontrolnu grupu, sa statistički značajnom razlikom uočenom samo u slučaju koncentracije LDL-holesterola. Otkriveno je da je hiperlipoproteinemija tipa lla povezana sa gotovo dvostruko većim rizikom od duboke venske tromboze (OR 1,99; $\mathrm{Cl} 1,01-3$, 90), dok lipoproteinemija tipa Ilb, IV ili hyperLp (a) nije uticala na rizik (OR 1,22; 95\% Cl 0,79-1,84; OR 0,89; 95\% Cl 0,52-1,54 ILI 1,85; 95\% Cl 0,84-4,04).

Zaključak: Hiperholesterolemija udvostručuje rizik od razvoja tromboze dubokih vena.

Ključne reči: DVT, hemostaza, hiperlipoptroteinemija, metabolizam lipida, Lp(a) hiperlipoproteinemija

lization, obesity, metabolic syndrome and diabetes, smoking, hypertension, malignancy, infection, and lipid metabolism disorders (9-12). Defects in cholesterol metabolism and hypercholesterolemia, which are major risk factors for atherosclerosis, have been shown to affect venous thrombosis risk, as well. Still, there is inconsistency in the results of different studies.

Additionally, it is known that one of the most atherogenic lipid particles, which is recognized as a significant risk factor for arterial thrombosis development, is Lp (a) lipoprotein (13-15). The structure of $\mathrm{Lp}$ (a) lipoprotein particle is similar to that of low-density lipoprotein (LDL) in terms of size and lipid composition, as well as the presence of apolipoprotein B100 (apo B100). The similarity of apo (a) with plasminogen was observed in the form of domains of inactive serine protease, whose amino acid sequence was $94 \%$ coincident with the amino acid sequence of plasminogen. Replacing serine with arginine at the activation site of this sequence results in the activation of the protease in the same way it does in the case of plasminogen, indicating the possibility of apo (a) activation by the presence of a tissue plasminogen activator (t-PA), urokinase and streptokinase. By finding a similarity between the structure of plasminogen and the Lp (a) particle, it was assumed that there was a connection between atherogenesis and thrombogenesis as well, with $\operatorname{Lp}(a)$ as the connecting link (16). A clear pathophysiological mechanism has not been proven, but the premise is that $L p$ (a) lipoprotein intervenes with the fibrinolysis system and competes with plasminogen for binding sites on endothelial cells, thereby inhibiting fibrinolysis and promoting intravascular coagulation (17). Studies evaluating the role of this specific lipoprotein in venous thrombosis appearance are scarce and inconsistent, as well.

Venous thrombosis is classified as primary (spontaneous) and provoked. This classification is very important because of the different therapeutic approaches between them. The long-term use of anticoagulant therapy in patients with spontaneous 
deep vein thrombosis has been indicated with the aim of reducing the high frequency (15-25\%) of symptomatic propagation of the thrombosis process and prevention of recurrence of venous thrombosis (18). However, bleeding remains the most common side effect of anticoagulant therapy. Lifelong oral anticoagulant therapy carries the risk of major hemorrhage of $2-3 \%$ per year (19). Thus, the primary goal is to define and detect all pathophysiological mechanisms and risk factors, which will ultimately lead to a reduction in the number of patients on lifelong OAT.

That is why the focus of newer researches, including ours, is to investigate the effect of lipid metabolism and its disorders as a contributing factor in the complex pathophysiology of venous thromboembolism.

\section{Materials and Methods}

\section{Study design}

The research was conducted within the Center for Laboratory Medicine, Clinical Center of Vojvodina and Department of Pathophysiology and Laboratory Medicine, Faculty of Medicine in Novi Sad, from October 2018 to July 2019. A total of 200 subjects participated in the study, 100 of whom experienced DVT with or without PTE, and 100 healthy subjects representing the control group. Data were obtained from patient records and supporting medical records.

The patient group consisted of 48 men (48\%) and 52 women (52\%). The youngest respondent was 19 years old, and the eldest 88, while the average age of the respondents was 52 years. The age range for inclusion in the study was 18 years and older. The control group of healthy subjects consisted of 100 persons, out of which 51 (51\%) were male, and 49 (49\%) were female. The average age was 50 years. The youngest respondent was 19, and the oldest was 87.

\section{Inclusion/exclusion criteria}

The basic criteria for the inclusion of the study participants were that they had experienced DVT or PTE. The diagnosis of DVT was confirmed based on clinical history and examination and supplementary imaging diagnostics in the form of a Duplex scan. The diagnosis of PTE was confirmed by lung perfusion scintigraphy with angiography. In each case, it was necessary that at least 3 months had elapsed since the clinical event, which excluded the possible impact of the acute phase response on the values of the parameters tested. Additionally, patients were enrolled in the study at least 3 months after discontinuing oral anticoagulant therapy in order to avoid the influence of these drugs on the functionality of the hemostatic mechanism.

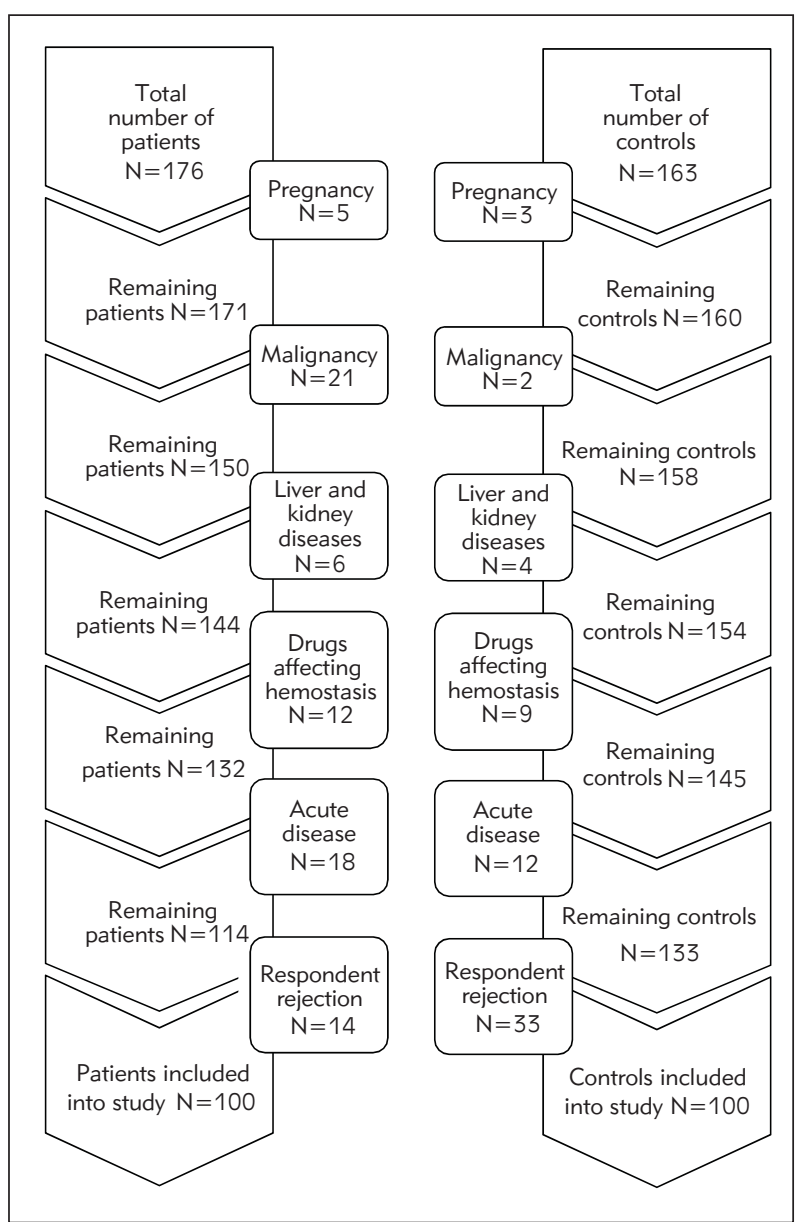

Figure 1 Selection of subjects in the patient and control group.

The exclusion criteria of the study included previously diagnosed disorders of hemostatic mechanism, current therapy that can affect the functionality of hemostatic mechanism with the exception of antiplatelet drugs, acute illness 6 weeks before blood sampling or at the time of sampling, malignancy, pregnancy, and puerperium, severe mental illness, liver and kidney diseases, autoimmune diseases, refusal of the subject to sign informed consent. The exclusion criteria for the control group of subjects were identical to the criteria for the patient group (Figure 1).

We classified patients and controls in terms of serum concentrations of chylomicrons, LDL, intermediate-density lipoprotein (IDL), very low-density lipoprotein (VLDL), and high-density lipoprotein (HDL) particles, into two categories - those with or without hyperlipoproteinemia. Additionally, in terms of serum Lp (a) lipoprotein levels, subjects were classified into those with hyperLp (a) lipoproteinemia (serum Lp (a) values $>0.3 \mathrm{~g} / \mathrm{L}$ ) and those without hyperLp (a) lipoproteinemia (serum Lp (a) values $<0.3 \mathrm{~g} / \mathrm{L}$ ) within both the patient and the control group. 
Finally, parameters used for diagnosing the type of hyperlipoproteinemia (serum levels of total cholesterol and triglycerides, HDL-cholesterol, refrigerated test) were based on the modified and supplemented Fredrickson classification participants with verified existences of hyperlipoproteinemia and classified into subgroups based on the type of hyperlipoproteinemia.

\section{Definition and data collection}

The analysis of blood lipids and Lp (a): serum extracted from whole blood after coagulation and a two-hour incubation period of the sample at room temperature were used for blood lipids and Lp (a) lipoprotein analyses. Lipid status parameters were assayed in fresh serum samples, while Lp (a) lipoproteins were determined from serum that was frozen at $-20{ }^{\circ} \mathrm{C}$ for less than a month.

Serum cholesterol concentrations as well as serum triglyceride concentrations were determined by a standardized enzyme procedure. The determination of cholesterol in the HDL fraction was performed by a direct enzymatic method for the quantitative determination of $\mathrm{HDL}$ cholesterol in human serum. LDL cholesterol values (Friedewald et al.) and non-HDL cholesterol (total cholesterol-HDL cholesterol), as well as atherosclerosis index (LDL cholesterol/HDL cholesterol) and atherogenic ratios (total choleste$\mathrm{rol} / \mathrm{HDL}$ cholesterol and non-HDL cholesterol/HDL cholesterol), were obtained by computation. Additionally, the characteristics of the serum after an 18-24-hour period at a temperature of $+4{ }^{\circ} \mathrm{C}$ was also evaluated.

Serum Lp (a) lipoprotein concentration was determined by the immunoturbidimetric method of Latex agglutination, using latex particles with monoclonal antibodies highly specific for Lp (a) lipoprotein, automatically. The Latex reagent contains microparticles of equal size, coated with monoclonal antibodies highly specific for Lp (a) lipoprotein. After mixing the serum sample with the Latex reagent, agglutination, which is directly proportional to the concentration of Lp (a) lipoprotein in the sample, occurs and is determined by a kinetic assay, measuring the increased absorption at $570 \mathrm{~nm}$ caused by the presence of the aggregate. The results are expressed in $\mathrm{g} / \mathrm{L}$.

\section{Statistical analysis}

Statistical data processing was performed using SPSS software, version 23.0 (SPSS, Chicago, IL, USA). Descriptive statistic methods were used to show the basic characteristics of the respondents. The Mann-Whitney $U$ test was used to test the statistical significance of differences for continuous variables having a normal distribution. Pearson's $c^{2}$ test was used to evaluate the differences in the frequency of individual parameters between different groups of subjects. A P-value of less than 0.05 was considered statistically significant in each of the before mentioned tests. Unconditional logistic regression was used to calculate ORs with $95 \% \mathrm{Cls}$ as a measure of the relative risks for venous thrombosis in participants with hyperlipoproteinemia compared with those without it. Lastly, the analysis was adjusted for all potential confounders (age, sex, obesity) related to the functionality of the lipid metabolism, which may have an impact on the risk of venous thrombosis.

\section{Results}

The basic characteristics of the respondents included in the study are presented in Table $I$. Recognized risk factors for the development of venous thrombosis are, as expected, more frequently present in patients than in the control group. An analysis of the prevalence of classical arterial thrombosis risk factors reveals that patients who have experienced venous thrombosis are more likely to be obese $(22 \%$ vs. $16 \%)$, smokers $(31 \%$ vs. $24 \%)$, or have hypertension ( $41 \%$ vs. $29 \%$ ) compared to healthy controls. Hyperlipoproteinemia (69\% vs. $54 \%$ ) and hyperLp (a) lipoproteinemia ( $20 \%$ vs. $12 \%$ ) were more commonly reported in patients with venous thrombosis than in the healthy controls.

Table I Clinical characteristics of the subjects ${ }^{1}$.

\begin{tabular}{|l|c|c|}
\hline & $\begin{array}{c}\text { Patients } \\
(n=100)\end{array}$ & $\begin{array}{c}\text { Controls } \\
(n=100)\end{array}$ \\
\hline General characteristics \\
\hline Male & $48(48)$ & $51(51)$ \\
\hline Female & $52(52)$ & $49(49)$ \\
\hline Age (years) & $52(19-88)$ & $50(19-87)$ \\
\hline Body mass index, & $27(17-39)$ & $26(18-37)$ \\
\hline Classic risk factors for venous thrombosis \\
\hline Present ${ }^{\dagger}$ & $44(44)$ & $15(15)$ \\
\hline Absent ${ }^{\dagger}$ & $56(56)$ & $85(85)$ \\
\hline Classic risk factors for arterial thrombosis \\
\hline Obesity & $22(22)$ & $16(16)$ \\
\hline Smoking & $31(31)$ & $24(24)$ \\
\hline Hypertension & $41(41)$ & $29(29)$ \\
\hline Prevalence of lipid metabolism disorders \\
\hline Hyperlipoproteine & $69(69)$ & $54(54)$ \\
\hline Hyper Lp (a) & $20(20)$ & $12(12)$ \\
\hline
\end{tabular}

${ }^{\dagger}$ Classic risk factors include surgery, malignancy, immobility, trauma, gypsum immobilization, use of hormonal medicaments, and longer travel.

${ }^{1}$ Values are $\mathrm{n}(\%)$ unless otherwise indicated. 


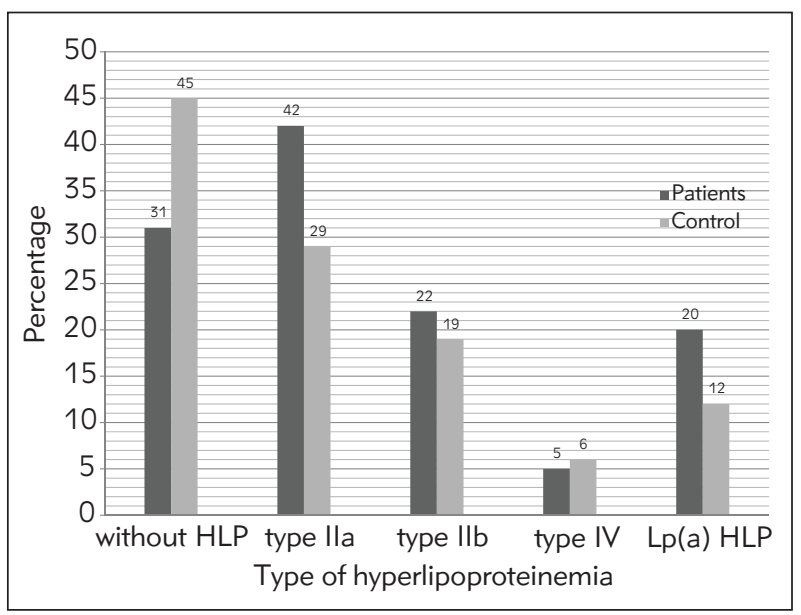

Figure 2 Distribution of hyperlipoproteinemia type in the patient group and the control group of subjects.
Table II Comparison of mean values of individual lipid status parameters between the patient group and the control group of healthy subjects.

\begin{tabular}{|l|c|c|c|}
\hline $\begin{array}{l}\text { Lipid status } \\
\text { parameters } \\
(\mathrm{mmol} / \mathrm{L})\end{array}$ & $\begin{array}{c}\text { Patients } \\
(\mathrm{n}=100)\end{array}$ & $\begin{array}{c}\text { Controls } \\
(\mathrm{n}=100)\end{array}$ & $\mathrm{p}$ \\
\hline $\begin{array}{l}\text { Total } \\
\text { cholesterol }\end{array}$ & $\begin{array}{c}5.93 \\
(3.32-9.20)\end{array}$ & $\begin{array}{c}5.52 \\
(2.78-8.09)\end{array}$ & 0.12 \\
\hline $\begin{array}{l}\text { Total } \\
\text { triglycerides }\end{array}$ & $\begin{array}{c}1.58 \\
(0.24-6.70)\end{array}$ & $\begin{array}{c}1.50 \\
(0.41-4.32)\end{array}$ & 0.550 \\
\hline LDL-cholesterol & $\begin{array}{c}3.83 \\
(1.49-6.26)\end{array}$ & $\begin{array}{c}3.44 \\
(1.29-5.56)\end{array}$ & 0.005 \\
\hline HDL-cholesterol & $\begin{array}{c}1.37 \\
(0.77-2.11)\end{array}$ & $\begin{array}{c}1.37 \\
(0.74-2.44)\end{array}$ & 0.892 \\
\hline
\end{tabular}

Values are given as means (range); LDL-low density lipoproteins; HDL-high density lipoproteins

Table III The risk of venous thrombosis in relation to the type of hyperlipoproteinemia.

\begin{tabular}{|l|c|c|c|c|}
\hline Type of hyperlipoproteinemia & Patients & Controls & OR $^{*}$ & OR $^{\dagger}$ \\
\hline $\begin{array}{l}\text { Without } \\
\text { hyperlipoproteinemia }\end{array}$ & $31(31)$ & $45(45)$ & 1.0 (Reference) & 1,0 (Reference) \\
\hline Type Ila & $42(42)$ & $29(29)$ & $2.05(1.05-4.00)$ & $1.99(1.01-3.90)$ \\
\hline Type Ilb & $22(22)$ & $19(19)$ & $1.25(0.84-1.85)$ & $1.22(0.79-1.84)$ \\
\hline Type IV & $5(5)$ & $6(6)$ & $0.99(0.64-1.55)$ & $0.89(0.52-1.54)$ \\
\hline $\begin{array}{l}\text { Lp (a) } \\
\text { hyperlipoproteinemia }\end{array}$ & $20(20)$ & $12(12)$ & $1.81(0.83-3.95)$ & $1.85(0.84-4.04)$ \\
\hline
\end{tabular}

* adjusted for gender and age

$\dagger$ Adjusted for gender, age, and obesity

By analyzing the distribution of hyperlipoproteinemia types in the patient group and the control group, results showing a more frequent presence of type Ila and IIb hyperlipoproteinemia in the patient group compared to the control group were obtained, as shown in Figure 2.

The results of the comparison of the mean values of individual lipid status parameters between the patient group and the control group clearly indicate higher concentrations of total cholesterol (5.93 $\mathrm{mmol} / \mathrm{L}$ vs. $5.52 \mathrm{mmol} / \mathrm{L})$, total triglycerides $(1.58$ $\mathrm{mmol} / \mathrm{L}$ vs. $1.50 \mathrm{mmol} / \mathrm{L})$, and $\mathrm{LDL}$-cholesterol $(3.83 \mathrm{mmol} / \mathrm{L}$ vs. $3.44 \mathrm{mmol} / \mathrm{L})$ in the patient group than in the control group, with a statistically significant difference observed only in the case of LDL-cholesterol concentrations, as shown in Table II.

The results presented in Table III show an assessment of the risk of venous thrombosis in relation to the type of hyperlipoproteinemia, after adjustment for confounding factors, and clearly suggest a statistically significant effect of type lla hyperlipoproteinemia on the risk of venous thrombosis, given the fact that fully adjusted OR was 1.99 (Cl 1.01-3.90), indicating that this type of hyperlipoproteinemia doubles the risk for venous thrombosis.

\section{Discussion}

Given the fact that thrombosis is a significant cause of mortality and morbidity in developed countries, scientists and medical professionals have devoted themselves to studying the etiology and pathophysiological mechanisms leading to it, which could potentially serve as a tool for adequate prevention and treatment. In previous years, the main focus was directed to arterial thrombosis and its most common complications, myocardial infarction, and ischemictype cerebrovascular stroke, but lately, the focus has been shifted to venous thrombosis. A number of different risk factors that have been proven to contribute to the occurrence of venous thrombosis are indicative of the multifactorial etiology in the onset of this disease and the relationship between arterial and venous thrombosis, and the risk factors common to these two 
thrombotic processes is of utmost importance. Research conducted by Prandoni P et al. (20) showed the relationship between atherosclerosis and the occurrence of venous thrombosis, based on which it was assumed that common etiological factors contribute to the onset of these diseases. Among them, the influence of hyperlipoproteinemia is of particular interest.

Our study included a total of 200 subjects, 100 of whom had experienced venous thrombosis and 100 laboratory and clinically proven healthy volunteers who had never experienced venous thrombosis. The results showed, above all, a higher percentage of hyperlipoproteinemia in the patient group than in the control group (69\% vs. $45 \%$ ), consistent with the results of the study by Vaýo A et al. (21) suggesting that hyperlipoproteinemia might be a risk factor for venous thrombosis. Additionally, a study conducted by Ray JG, et al. (22) showed that usage of hypolipemics, particularly statins, reduces the risk of venous thrombosis. The results of our study also indicate a more frequent occurrence of Lp (a) hyperlipoproteinemia in subjects in the patient group than in control subjects $(20 \%$ vs. 12\%). The results of the study by Nowak-Goottl et al. (23) showed higher levels of $\mathrm{Lp}$ (a) lipoprotein in the serum of patients with DVT. The significance of elevated serum Lp (a) lipoprotein was also demonstrated in the study conducted by Sofi et al. (24). On the other hand, the research by McColl MD et al. (25) did not show a statistically significant elevation of serum $\mathrm{Lp}(\mathrm{a})$ in DVT patients. Comparison of mean values of individual lipid status parameters between the patient group and control group of healthy subjects showed statistically significant difference only when it came to LDLcholesterol values $(3.84 \mathrm{mmol} / \mathrm{L}$ vs. $3.45 \mathrm{mmol} / \mathrm{L} \mathrm{p}=$ $0.005)$. Similar results were obtained by Albert $W$ et al. (26). Moreover, a study by Kawasaki et al. (27) showed a significant impact of hypertriglyceridemia and hypercholesterolemia as risk factors for DVT. Deguchi et al. demonstrated the importance of LDLcholesterol as a risk factor for venous thrombosis, as well (28). Hyperlipoproteinemia type distribution showed a higher prevalence of type lla hyperlipoproteinemia in the patient group compared to the control group ( $42 \%$ vs. $29 \%)$ as well as type Ilb (22\% vs. $19 \%)$, which is consistent with the results of Carvalho et al. (29). Such results were also shown in the study of Deguchi et al. (28).

Unconditional logistic regression was used to assess the relative risk of venous thrombosis in patients with different types of hyperlipoproteinemia, and it was adjusted for age, gender, and obesity, as potential confounders. "Confounding" is a type of bias, implying a situation in which the effect of variables whose influence on a parameter we examine is mixed with the influence of another variable, which can cause bias, that is, a gross error in the interpretation of the obtained results. In other words, the "confounder must have a proven relationship to the disease (as an immediate causative factor but not as an effect of the disease), as well as with the factor whose causal relationship to the disease is being examined. If the potential impact of "confounding" is not taken into account when designing the study, there is a risk of misinterpretation of the results. Therefore, in our study, we paid particular attention to eliminating the influence of "confounding " variables in statistical data processing and interpretation of the obtained results. Using unconditional logistic regression to evaluate the effect of different types of HLP on the risk of deep vein thrombosis, we have found that type lla hyperlipoproteinemia is associated with a nearly doubled risk for deep vein thrombosis (OR 1.99; $\mathrm{Cl} 1.01-$ 3.90), while type IIb, IV, or hyperLp (a) lipoproteinemia didn't influence this risk (OR 1.22; $95 \% \mathrm{Cl} 0.79$ 1.84; OR 0.89; 95\% Cl 0.52-1.54 OR 1.85; 95\% Cl 0.84-4.04). In light of our results, hypercholesterolemia can be identified as one of the potential risk factors for the development of DVT. By promoting endothelial dysfunction, it can influence complex regulation of the hemostatic mechanism, triggered by decreased concentrations of tissue factor pathway inhibitor (TFPI) and thrombomodulin. TFPI is synthesized mainly in endothelial cells, and it is detected that the free form of TFPI is transferred to the LDL/VLDL fraction due to the increase in LDL, which may cause a reduction in endothelial cell-associated TFPI. Increased concentrations of cholesterol can be treated with statins, and there is some evidence that these drugs decrease thrombosis risk, not only by lowering cholesterol levels but by stabilizing endothelial cells as well. As the majority of studies dealing with this topic have a small number of participants, a welldesigned meta-analysis could give us a final answer on whether we should consider hypercholesterolemia as a risk factor for venous thrombosis and use statins in the prevention of this disease.

\section{Conclusion}

We conclude that type lla hyperlipoproteinemia doubles venous thrombosis risk.

\section{Author declaration}

Authors certify that the manuscript represents a valid piece of work and neither this manuscript nor one with substantially similar content under named authorship has been published or is being considered for publication elsewhere. The authors have participated in the research and the shaping of the manuscript.

\section{Conflict of interest statement}

The authors have no conflicts of interest to declare. The authors give consent to the submission and publication of the work. Authors disclose no relationship to any organization or industrial manufacture in any material discussed. 


\section{References}

1. Cohen AT, Agnelli G, Anderson FA, et al. Venous thromboembolism (VTE) in Europe. Thrombosis and haemostasis 2007; 98(10): 756-64.

2. Naess IA, Christiansen SC, Romundstad P, Cannegieter SC, et al. Incidence and mortality of venous thrombosis: a population-based study. J Thromb Haemost 2007; 5: 692-9.

3. Stošić Z, Đerić M. Praktikum iz patološke fiziologije. Novi Sad. Medicinski fakultet; 2012.

4. Heit JA, Mohr DN. Silverstein MD, et al. Predictors of recurrence after deep vein thrombosis and pulmonary embolism: a population-based cohort study. Archives of internal medicine 2000; 160(6): 761-8.

5. Virchow R. Phlogose und Thrombose im Gefä system; Gesammelte Abhandlungen zur Wissenschaftlichen Medizin. Staatsdruckerei, Frankfurt, 1856.

6. Đurđević S. Kopitović V. Kapamardžija A. Ginekologija. Novi Sad. Medicinski fakultet; 2011.

7. Rosendaal FR. Venous thrombosis: a multicausal disease. Lancet 1999; 353: 1167-73.

8. McColl MD, Ramsay JE, Tait RC, et al. Risk factors for pregnancy associated venous thromboembolism. Thromb Haemost 1997; 78: 1183-8.

9. Nordström M, Lindblad B, Anderson H, Bergqvist D, Kjellström T. Deep venous thrombosis and occult malignancy: an epidemiological study. Br Med J 1994; 308: 891-4.

10. Ginsberg JS, Wells PS, Brill-Edwards P, et al. Antiphospolipid antibodies and venous thromboembolism. Blood 1995; 86: 3685-91.

11. Pomp ER, le Cessie S, Rosendaal FR, Doggen CJ. Risk of venous thrombosis: obesity and its joint effect with oral contraceptive use and prothrombotic mutations. $\mathrm{Br} \mathrm{J}$ Haematol 2007; 139: 289-96.

12. Hansson PO, Eriksson H, Welin L, Svardsudd K, Wilhelmsen L. Smoking and abdominal obesity: risk factors for venous thromboembolism among middle-aged men: „The Study of Men Born in 1913«. Arch Intern Med 1999; 159: 1886-90.

13. Prandoni P, Ghirarduzzi A, Prins, MH, Pengo V, Davidson, BL. Sørensen H, \& Pagnan A. Venous thromboembolism and the risk of subsequent symptomatic atherosclerosis. Journal of Thrombosis and Haemostasis 2006; 4(9): 1891-6.

14. Gordon T, Kannel WB. Predisposition to atherosclerosis in the head, heart and legs. The Framingham Study. The Journal of the American Medical Association 1972; 221: 661-6.

15. Hume M, Sevitt S, Thomas DP. Venous Thrombosis and Pulmonary Embolism. Harvard University Press, Cambridge, MA, 1970.

16. Rumley A, Emberson JR, Wannamethee SG, Lennon L, Whincup PH, Lowe GD. Effects of older age on fibrin Ddimer, C-reactive protein and other hemostatic and inflammatory variables in men aged $60-79$ years. Journal of Thrombosis and Haemostasis 2006; 4: 982-7.
17. Smeeth L, Cook C, Thomas S, Hall AJ, Hubbard R, Vallance $\mathrm{P}$. Risk of deep vein thrombosis and pulmonary embolism after acute infection in a community setting. Lancet 2006; 367: 1075-9.

18. Collins R, Scrimgeour A, Yusuf S, Peto R. Reduction in fatal pulmonary embolism and venous thrombosis by perioperative administration of subcutaneous heparin. $\mathrm{N}$ Engl J Med 1988; 318(18): 1162-73.

19. Leonardi MJ, McGory ML, Ko CY. The rate of bleeding complications after pharmacologic deep venous thrombosis prophylaxis: a systematic review of 33 randomized controlled trials. Arch Surg 2006; 141(8): 790-7.

20. Prandoni P, Villalta S, Tormene D, Spiezia L, Pesavento R. Immobilisation resulting from chronic medical diseases: a new risk factor for recurrent venous thromboembolism in anticoagulated patients. Journal of Thrombosis and Haemostasis 2007; 5: 1786-7.

21. Vaýo A, Mira Y, Ferrando F, Conteras M, Estelles A, Espa a F. Hyperlipidaemia and venous thromboembolism in patients lacking thrombophilic risk factors BJH 2002; 118: 255-9.

22. Ray JG, Mamdani M, Tsuyuki RT, Anderson DR, Yeo EL, Laupacis A. Use of statins and the subsequent development of deep vein thrombosis. Arch Intern Med 2001; 161: 1405-10.

23. Nowak-Gottl U, Junker $R$, Hartmeier $M$, Koch HG, Munchow N, Assmann G, von Eckardstein, A. Increased lipoprotein (a) is an important risk factor for venous thromboembolism in childhood. Circulation 1999; 100 (7): 743-8.

24. Sofi F, Marcucci R, Abbate R, Gensini GF, Prisco D. Lipoprotein (a) and venous thromboembolism in adults: a meta-analysis. The American Journal of Medicine 2007; 120 (8): 728-33.

25. McColl MD, Sattar N, Ellison J, Tait RC, Walker ID, Packard CJ, et al. Lipoprotein(a), cholesterol and tryglycerides in women with venous thromboembolism. Blood Coagul Fibrinolysis 2000; 11: 225-9.

26. Tsai AW, Cushman M, Rosamond WD, Heckbert SR, Polak JF, Folsom AR. Cardiovascular risk factors and venous thromboembolism incidence: the longitudinal investigation of thromboembolism etiology. Archives of Internal Medicine 2002; 162(10): 1182-9.

27. Kawasaki T, Kambayashi Jl, Ariyoshi H, Sakon M, Suehisa E, Monden M. Hypercholesterolemia as a risk factor for deep-vein thrombosis. Thrombosis Research 1997; 88(1): 67-73.

28. Deguchi H, Pecheniuk NM, Elias DJ, Averell PM, Griffin $\mathrm{JH}$. High-density lipoprotein deficiency and dyslipoproteinemia associated with venous thrombosis in men. Circulation 2005; 112(6): 893-9.

29. Carvalho AC, Lees RS, Vaillancourt RA, Cabral RB, Weinberg RM, Colman RW. Intravascular coagulation in hyperlipidemia. Thrombosis Research 1976; 8(6): 843-57. 